\title{
The Influence of Scale Preferences on the Design of a Water Innovation: A Case in Dutch River Management
}

\author{
Heleen Vreudenhil • Jill Slinger • Emiel Kater • \\ Wil Thissen
}

Received: 12 January 2009/Accepted: 21 June 2010/Published online: 18 July 2010

(C) The Author(s) 2010. This article is published with open access at Springerlink.com

\begin{abstract}
The debate on scale use in river management focuses primarily on the (lack of) fit between the biogeophysical and institutional systems. However, in this article we focus on the 'subjective' aspect of scale preferences in water governance. We apply an adapted version of the Integrated Scale Hierarchy for Rivers to determine the degree of fit between the scale preferences of the actors involved in a Dutch case study and the scale requirements of the innovative river management concept. This allows us to understand which riverine processes and characteristics are regarded as important by the different actors and to identify mismatches in scale perspectives as they manifest themselves in water management practice. We discover that inflexibility in scale use on the part of the involved actors places bounds on the design and quality of interventions and demonstrate that a more flexible use of scales in the design phase of a river management intervention has the potential to lead to more effective solutions.
\end{abstract}

Keywords River management - Scale preferences · Flexible scale use $\cdot$ Pilot project . Cyclic floodplain rejuvenation - Water governance - Integrated scale hierarchy $\cdot$ Hydrodynamic modelling $\cdot$ Multi actor systems

H. Vreudenhil $(\bowtie) \cdot$ J. Slinger · W. Thissen

Faculty of Technology, Policy and Management, Delft

University of Technology, Jaffalaan 5, 2628 BX Delft,

The Netherlands

e-mail: h.s.i.vreugdenhil@tudelft.nl

E. Kater

Centre for Water and Society, Radboud University,

Nijmegen, The Netherlands

\section{Introduction}

The spatial and temporal fit between biophysical and institutional scales is known to influence the effectiveness of environmental institutions in floodplain restoration (Moss 2007; Young 2002). Meadowcroft (2002), amongst others, support the view of a misfit in institutionalized scales as a source of problems in water governance. The term (mis)fit refers to the partial (mis)match between institutional arrangements and the bio-geophysical system. Spatial misfits are present when organisations are tasked with responsibilities for areas that do not match geographically with the bio-geophysical system. This leaves the organisations with the inability to internalise external effects. Temporal misfits occur when the short time-frames commonly adopted by institutions for river management, i.e. the focus on projects of limited duration and the influence of electoral periods, do not cohere with the dominant time scales in the bio-geophysical system. In river basin management, the misfit between bio-geophysical and institutional scales is considered a major limitation in implementing management approaches that accommodate the natural functioning of the river system (Lee 1999; Cash and others 2006). Indeed, "floodplains are characterized by their dependence on flooding events, which are by their nature periodic and unpredictable .... However, many institutional arrangements, in particular for nature conservation, exhibit a strong tendency to protect existing conditions rather than encourage change" (Moss and Monstadt 2008, pp. 7, 8). In this article we call attention to this institutional inertia or lack of flexibility in scale use by examining the effects of scale preferences on the design of an innovation for floodplain management along the Waal River in the Netherlands. 
Our institutional focus is not at organisational/interorganisational level of rule-setting, instead we adopt a multi-actor systems analytical lens in which we deliberately examine the scale preferences of individual actors. By focusing on the 'subjective' aspects of scale issues, we aim to contribute to the debate on scale use in river management which focuses primarily on the (lack of) fit between the bio-geophysical and institutional systems. The rationale for this choice arises from the understanding that river systems can be viewed from different perspectives. The diversity in perspectives increases the overall understanding of complex river systems and helps to address the multiple demands society places upon this natural resource. Indeed, many scale classifications are in use to structure the diversity of perspectives on rivers (Jewitt 1998). We adopt an analytical stance similar to Karstens and others (2004) who claim that actors hold different scale perspectives deriving from their various disciplinary backgrounds and different institutional roles.

We re-examine the theoretical basis of the Integrated Scale Hierarchy (Vreugdenhil and others 2008) (ISH), reviewing and adapting it for use as analytical framework to investigate how the scale preferences of actors in a pilot project along the Waal River in the Netherlands differ and how these differences influence the design and quality of interventions. The pilot project represents an innovation in Dutch river management in that it seeks to imitate the natural ecological and morphological functioning of the floodplain at Beuningen/Ewijk on the Waal River, thereby enhancing its robustness and resilience to flooding (Peters and others 2004). This is in contrast to standard practice which would seek to uproot established forest to enhance river discharge capacities and maintain flooding safety standards. In the pilot project a coalition of actors attempts to learn about the design of floodplain restoration measures that address existing problems yet also translate an innovative concept into practice. We deepen understanding of the scale issues and their effects using hydrodynamic modeling to explore the validity of the scale-based arguments used by the actors involved in the pilot project.

Whereas Vreugdenhil and others (2008) primarily compare and contrast the different scale perspectives present in Dutch river management, in this article we demonstrate that inflexibility in scale use on the part of actors involved in an innovation in Dutch water management can act to constrain effective intervention and that a more flexible use of scales in the design phase of a river management intervention could lead to more effective solutions. This concurs with Gunderson (1999), who demonstrated that flexibility enables actors to deal with uncertainties and the dynamics of a river system.

\section{An Analytical Framework for Comparing Scale Perspectives on Rivers}

An analytical framework to support the assessment of scalar mismatches in river management practice is developed using that of Vreugdenhil and others (2008) as a basis. The eight scale classifications discussed below are not definitive for the different disciplinary fields, but are presented as a first step in distinguishing the different perspectives and scale preferences held by the actors actively involved in river management in the Netherlands.

\section{Disciplinary and Managerial Scale Perspectives on Rivers}

Vreugdenhil and others (2008) distinguish four biophysical scale perspectives that derive from the geological, ecological, hydrological and bio-geomorphological disciplines and four scale perspectives that derive from the practice of managing a river. In contrast to Vreugdenhil and others (2008), we (i) include economics in the disciplinary scale perspectives, (ii) view engineering as a disciplinary scale perspective, and (iii) distinguish only two managerial scale perspectives, namely that of river management and a public administration/planning perspective. Whereas the managerial scale perspectives are grounded in Dutch river management, the disciplinary scale perspectives are generically applicable. Despite the low relevance of economic activities in the pilot studyall farms are no longer active and are represented by a NGO-we have included an economic disciplinary perspective in the interest of increasing the generic applicability of the analytical framework. It may be necessary to include these scale perspectives in a more detailed way if a similar analysis were conducted in another area of the Netherlands or in another country. Each of our eight scale perspectives is based on a hierarchy. Haufler and others (1997) define a hierarchy as 'a formal organization of various spatial or temporal sizes or levels graded from small to large'. Thus, in a hierarchy a physical or environmental system is divided into levels that share time and space scales and that interact systematically with higher and lower levels. In moving from a lower to a higher level (scaling up), less detail and more information on the context becomes available. In moving from a higher to a lower level (scaling down), more detailed information becomes available and patterns and relationships become less obvious (Jewitt 1998). 
The Geomorphological Disciplinary Perspective

In geological terms, rivers are temporary features. On a time scale of millennia, river basins can be formed, join together or even disappear. On a time scale of centuries, the influence of man on the form of a river can be significant. Indeed, by constructing dikes and reclaiming land from the sea, the people of the Netherlands have altered the form of the rivers and their surrounding landscapes. However, Cooper and others (1999) claim that the context for interpreting observed changes is provided by an understanding of the functioning of a river or estuary on a time scale of decades. Accordingly riverine geomorphologists generally focus at the temporal and the related spatial meso-level. The spatial level derives from the morphodynamics that shape catchments and flows and move particles in processes ranging from scouring (micro-level) to section or branch shaping (meso-level) and river evolution (macrolevel).

\section{The Ecological Disciplinary Perspective}

Petts and Amoros (1996) view a river as a three dimensional system, in which complex ecological interactions can be distinguished. Their scale hierarchy ranges from the drainage basin to meso-habitats via sectors, sets and units. At a drainage basin level, the river is regarded as a continuum. Characteristics of sectors include variety in channel patterns, process regimes and biotope types. Sets are ecological entities associated with specific landforms, strongly influenced by dynamic morphological processes. Units are characterized by typical animal and plant communities indicative of the habitat conditions and generally arranged in spatial successions along topographic gradients in 'mosaic patterns' (Geerling and others 2006). Mesohabitats include ephemeral, individual units such as a sand bar. It is at the dynamic meso-habitat level that the concept of time-varying, species niches can be applied in practice. In contrast, the drainage basin represents the appropriate level when studying the ecology of a river as a whole, since at this level the river may be viewed as a continuum.

\section{The Hydrological Disciplinary Perspective}

Schultze (1995) describes the problem of hydrological modelling as one of "dealing with a system characterized by large temporal and spatial fluctuations, irregularities and discrepancies which occur more or less regularly through a series of dynamic, non-linearly lagged responses with feedback between elements of the system". In this he concurs with Dooge (1984) and the Committee on Opportunities in the Hydrologic Sciences (COHS 1991) when they describe the hydrological cycle as transcending a wide spectrum of space and time scales. Dooge (1984) defines these spatial scales as varying from that of an individual water molecule (length scale of $10^{-10} \mathrm{~m}$ ), through the scales associated with turbulent flow (length scale of $10^{-2} \mathrm{~m}$ ) to a water basin level of scale of $10^{4}-10^{5}$ $\mathrm{m}$ and beyond. Processes of interest at the larger levels of scale include for instance rainfall patterns and flow regimes. For each of these hydrologists, the primary purpose in distinguishing the different space and time scales is to achieve clarity on which processes are taken into account in their hydrological models.

\section{The Bio-Geomorphological Disciplinary Perspective}

Bio-geomorphology focuses on the interaction between geomorphology and ecology. Classification systems have been developed to emphasize the relationship of a river and the aquatic habitat it provides to the landscape through which it flows over a wide range of scales, including that of the catchment (Jewitt 1998). Based on the classification of Frissell and others (1986) for small mountain streams, Klijn (1997) developed a classification for river systems such as the Rhine. Baptist (2001), in turn, used this as a basis for his bio-geomorphological classification in which he assigned characteristic length scales to a river basin $\left(10^{5}-10^{7} \mathrm{~m}\right)$, a river segment $\left(10^{5}-10^{6} \mathrm{~m}\right)$, a river reach $\left(10^{3}-10^{5} \mathrm{~m}\right)$, an ecotope $\left(10-10^{3} \mathrm{~m}\right)$ and an eco-element $(1-10 \mathrm{~m})$. The underlying rationale involves associating spatial length scales with characteristic dynamic processes occurring in a river. Processes of importance to a biogeomorphologist include the rejuvenation of species that occurs at the ecotope level or the pattern forming and succession that occurs at the reach level. Processes at the reach level are of major importance in understanding floodplain dynamics and the development of vegetation mosaics (Moss and Monstadt 2008).

\section{The Economic Disciplinary Perspective}

The economic perspective focuses primarily on the size of the workforce, the location of economic operations and the extent of the market. Economic enterprises are most commonly classified as small, medium or micro-enterprises (SMME's) and national or multi-national companies. Over the last 30 years economic research has evinced interest in the innovative behaviour of firms, particularly in relation to the competitive conditions prevailing in a region (Bertuglia and others 1998). Regions are regarded as important nodes of production, consumption, trade and decision-making and play a critical role in global modes of production and transportation (Nijkamp 2000). From a regional economic perspective, much research has been undertaken on the geographical differentiation in the birth and growth process 
of new firms and the role of the entrepreneur therein (Keeble and Wever 1986; Suarez-Villa 1996; Sutton 1998). Entrepreneurial activities such as industrial development, mining, property development and farming, amongst others, are manifested in the physical domain via their use of land and other resources (e.g. water for cooling or irrigation). The geographical extent of their manifestation together with the degree of influence that an enterprise exerts on the local, regional and national economy defines the local, regional, national and multi-national scales of interest to an economic geographer.

\section{The River Engineering Disciplinary Perspective}

In contrast to the biophysical orientation of the first four disciplinary perspectives, the river engineering perspective is primarily one of safety and navigation. In the Netherlands, dikes were built to protect the surrounding countryside from flooding and the navigability of the rivers has been improved. The primary scale of design and analysis for the purposes of both flooding safety and navigability is the river branch or tributary. This is a pragmatic choice, because it is at this level that the effects of engineering designs can best be assessed and stability of the river bed maintained. Micro-levels are also of interest in maintaining the stability of the dikes and so ensuring safety from flooding.

\section{The River Management Perspective}

The Dutch Ministry of Transport, Public Works and Water Management uses a practice-orientated scale hierarchy in their management of a river, namely: the river basin or branch level, delineated by international boundaries, such as the Rhine or Scheldt in the Netherlands for which they develop integrated management plans, and river branches (tributaries) when river engineering works and their effects are being considered. The operational arm of the ministry (Rijkswaterstaat or RWS) focuses in its operational river management on the attainment of sufficient discharge capacity to guarantee safety from flooding under reference conditions (such as peak discharges of $16000 \mathrm{~m}^{3} \mathrm{~s}^{-1}$ at Lobith on the Dutch-German border). The law related to flooding safety and river management specifies that land owners bear responsibility for ensuring that the discharge capacity of a river is not reduced by obstacles on their land and gives the RWS the authority to ensure compliance. Similarly, the formation of a sand bank in the channel is viewed as a threat to navigability. It is common practice to focus at floodplain level either to eliminate the cause of on obstruction that is reducing the discharge capacity (e.g. construction activities, vegetation development) or to compensate for the obstruction near the cause, that is on the land of the responsible landowner.

\section{The Public Administration and Planning Perspective}

The spatial levels distinguished by public administrators and spatial planners relate to administrative borders such as the trans-national level of river basin planning, the national level at which national water resource policy plans are made, the provincial level where spatial plans are made, the local or municipal level where local land use plans are made and the level of individual households. Water management boundaries usually cross these administrative boundaries. This is clearly the case for large rivers such as the Rhine, which extends from Switzerland to the Netherlands, but can also occur when municipal boundaries cut across the river branch for which a regional division of the RWS (e.g. the Eastern Netherlands section) carries responsibility.

In the Netherlands, local and provincial authorities carry responsibility for enabling economic activities within their boundaries both now and in the future, upholding the law and administering existing policies. This means that the primary focus of a Dutch municipality is on the provision of public services, the collection of local taxes to fund these and the maintenance of current living standards. Municipalities and provincial authorities are also responsible for process management and communicating with the public. In addition, national authorities carry responsibilities for making international agreements on a river basin level and translating these into national policies. Issues addressed concern the maintenance of navigation channels, and the ecological quality of the river as required by the EU Water Framework Directive. Flood defence levels are set at a national level and strategic plans based on the national standards are developed and implemented in the form of multiple projects each characterized by a relatively short term focus. This practice of implementing strategic plans through multiple, short term projects together with a four yearly electoral time scale, means that Dutch public administrative bodies have long term responsibilities, but exercise a shorter term temporal focus in practice.

\section{The Integrated Scale Hierarchy for Rivers}

An amplified, adapted and inverted version of the Integrated Scale Hierarchy for rivers is presented in this article (Fig. 1). The bio-geomorphological scale classification (from river basin to eco-element) defined by Baptist (2001) is still selected as the basis for the Integrated Scale Hierarchy, appearing on the left hand side of the diagram. The major processes and characteristics of interest to the biogeomorphological as well as the seven other disciplinary 
Fig. 1 The Integrated Scale Hierarchy for rivers with the major processes and characteristics of interest per level derived from the different disciplinary and management perspectives. The biogeomorphological scale classification is used as the basis and appears on the left hand side (adapted from Vreugdenhil and others 2008)

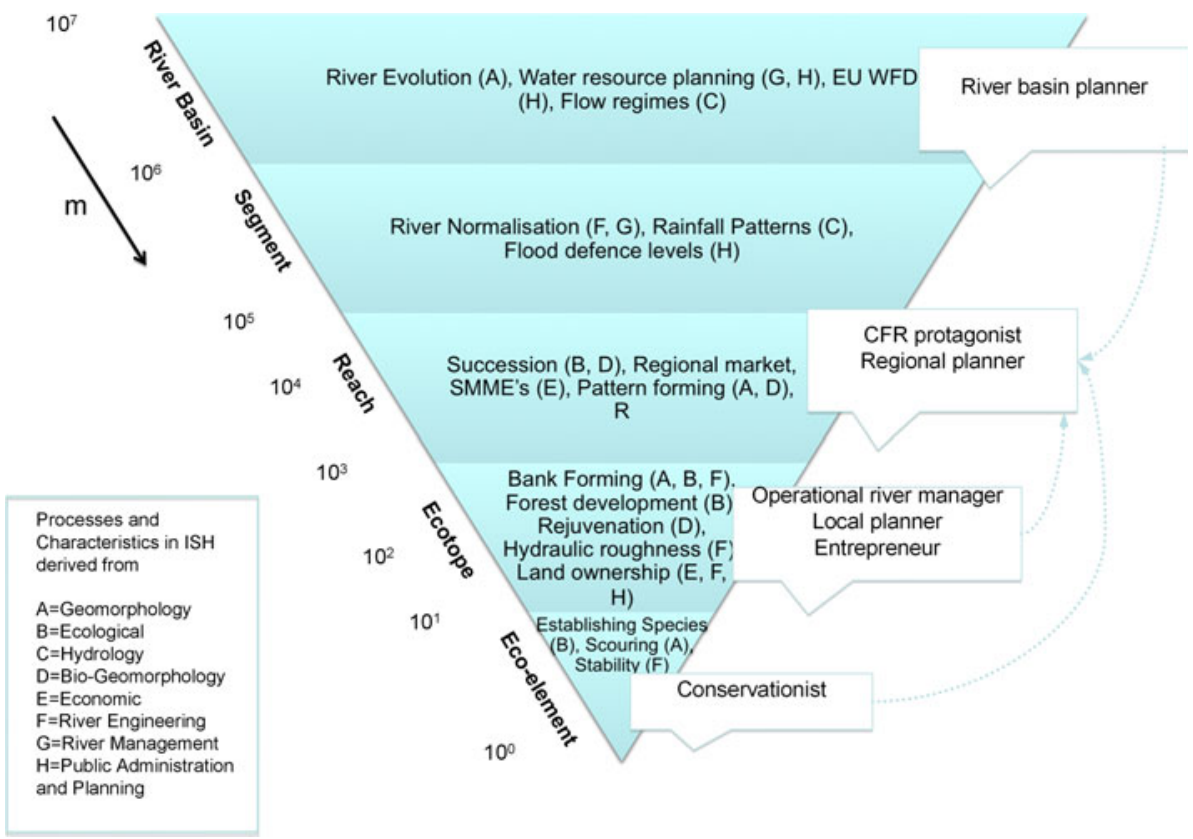

and managerial scale perspectives are then placed within the appropriate level of the hierarchy. Of particular interest is the floodplain level classification of river engineers and managers that appear at the upper part of the ecotope level that is indicated in the ISH. Examples of processes and characteristics of interest include the geomorphological process of scouring, which is depicted at the eco-element level, and water resource planning, which is depicted at the river basin level. By subsequently projecting the scale perspectives of different types of actors from a particular case study onto the right hand side of the diagram, identification of the degree of fit between the scale preferences of the involved actors and the scale requirements of the underlying bio-geomorphological concept is facilitated. This allows us to understand which riverine processes and characteristics are regarded as important by the different actors and to identify mismatches in scale perspectives. As such, the Integrated Scale Hierarchy for Rivers represents an analytical framework for assessing scalar mismatches as they manifest themselves in water management practice.

\section{Method}

In this article we study the influence of scale preferences on the design of a water innovation in Dutch river management, in particular the case of a pilot project on the river Waal. In the piloting process, experience from different disciplines and interests from different stakeholders come together. Pilot projects are policy instruments that can be used by different actors for different purposes, including research, managerial and political-entrepreneurial ends (Vreugdenhil and others, 2010). We identify the different actors, their roles in the process, their scale preferences and their contribution to the design process. The Integrated Scale Hierarchy for Rivers is used as the analytical framework on the basis of which the scale preferences of different actors are assessed and contrasted with the perspective underlying the innovative concept. The empirical data used in this assessment derive from three sources, namely:

- A series of interviews with nine actors involved in the Beuningen/Ewijk pilot project, from 2004 to 2008 yielded information on their scale use and preferences.

- Attendance of project meetings, discussions and ongoing participation in the process of designing potential interventions on the Beuningen/Ewijk floodplain by the first and third authors. The third author participated actively in the project on behalf of the Radboud University Nijmegen. The analysis of the influence of scale perceptions on the floodplain management innovation formed the primary task of the first author.

- A survey amongst participants at a pilot project workshop held in January 2005. The workshop was attended by project participants and other interested parties, including representatives from local and regional authorities not themselves directly involved with the project, scientists and representatives of environmental interest groups. The survey comprised 3 open and 1 closed question about scale preferences in floodplain management of the study area, their reasons 
Fig. 2 The floodplains of Beuningen/Ewijk are located on the south bank of the Waal River, a tributary of the Rhine River, in the Netherlands. The sandbar of Ewijk (dashed line), the CFR testing site, is located on the floodplains of Beuningen (solid line) (adapted from RWSRIZA and Stichting Ark)

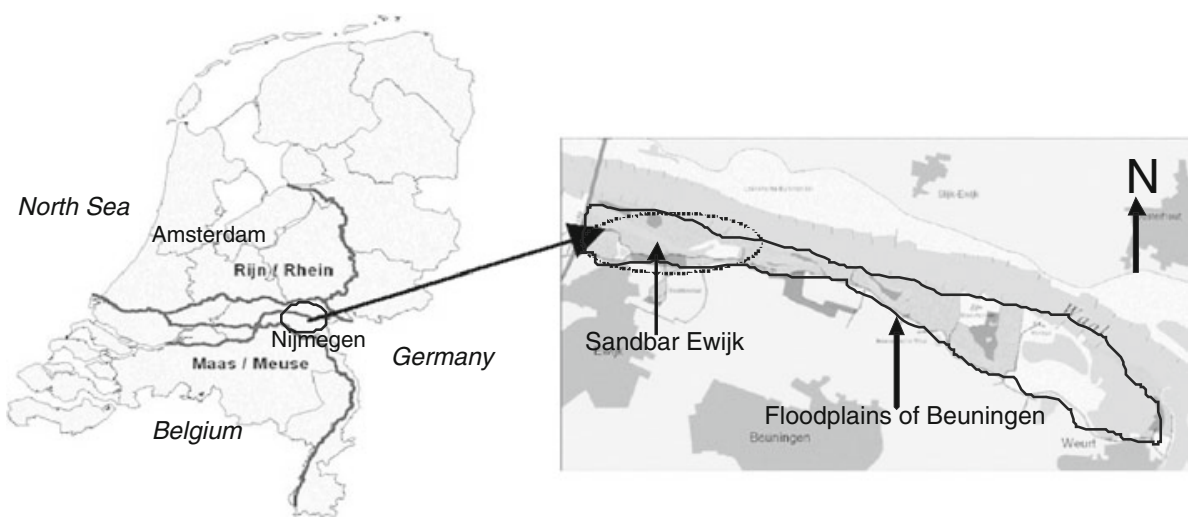

to focus at this scale and the anticipated consequences of scaling up. Twenty-four participants, representing science, the river authority, the forestry service, the municipality, the province, private partners and NGO's completed the survey.

The validity of the argumentation to focus on floodplain levels in designing and screening potential interventions was then examined by simulating the effects of the biogeomorhological interventions using a two-dimensional hydrodynamic model for Dutch river branches (Rijkswaterstaat 1992, 2005; Ministry of Transport, Public Works and Water Management 2006) in combination with the Blokkendoos. The Blokkendoos ('box of building blocks' in Dutch) is a software package designed to visualize the effects of interventions using pre-calculated hydrodynamic model runs (De Vriend and Dijkman 2003; Schielen and Gijsbers 2003; Kors 2004). This allowed the effects of the proposed interventions on water levels to be evaluated at a larger spatial scale and the maximum distance over which an intervention is effective to be investigated.

The site of the pilot project and the design and initial implementation of the interventions on the floodplains of Beuningen/Ewijk will now be described.

\section{The Beuningen/Ewijk Pilot Project}

Cultivation of the floodplains along the Waal (a branch of the Rhine) in the Netherlands has occurred for centuries. However, agricultural and pastoral practices have declined in importance over the last two decades, whereas nature restoration has grown in importance. Accordingly, several of the floodplains have gradually and intentionally been 'abandoned to nature'. Beuningen/Ewijk, located on the floodplains of the Waal near the city of Nijmegen (Fig. 2), is one of the first floodplains where 'nature' was allowed to take her course and open grassland has gradually been replaced by thick alluvial forest. The erosive processes, which would naturally reset the late successionary stage alluvial forest to pioneer vegetation, are restrained by engineering works such as groynes, and are affected by previous excavations of the floodplain, as well as the initial, unnaturally low grazing intensities. As a result, instead of being characterized by a mosaic of vegetation types and successionary stages, the floodplains of Beuningen/Ewijk are now covered by late successionary stage, densely vegetated stands of alluvial forest with limited species diversity. The stands of alluvial forest also reduce the discharge capacity of the river and increase the risk of flooding (Mannaerts 2004) leading to a conflict between nature on the one hand and safety issues on the other hand.

The bio-geomorphological concept of Cyclic Floodplain Rejuvenation was developed to address 'nature-safety dilemmas' in lowland rivers by imitating the natural ecological and morphological functioning of the river, thereby enhancing its robustness and resilience to flooding (Peters and others 2006). The nature-safety dilemma involves restoring discharge capacity (increasing safety from flooding) while maintaining ecological quality (nature). The Cyclic Floodplain Rejuvenation concept originates from the understanding that morphological processes continuously rework sediments in a river and provide the means of resetting vegetation to pioneer stages. The morphological processes of erosion and sedimentation, as well as grazing by large herbivores, act to create channels for water flow and increase the diversity in habitats for the establishment and growth of riverine and alluvial species (Smits and others 2000, p. 279; De Bruin and others 1987). These processes are largely absent in restrained river systems such as the Waal, but CFR aims to re-introduce and imitate them. CFR interventions could include digging secondary channels, excavating and lowering floodplains or removing and resetting vegetation in combination with grazing (Duel and others 2001).

In terms of Dutch law (wet beheer rijkswaterstaatwerken now included in the waterwet $^{1}$ ), action has to be taken to alleviate the increased risk of flooding resulting from the

\footnotetext{
${ }^{1}$ Information about the water law can be found online at http:// www.rijkswaterstaat.nl/water/wetten_en_regelgeving/waterwet/.
} 
abundant and ecologically valuable vegetation growth on the floodplain at Beuningen/Ewijk. Instead of the standard practice of simply removing the 'obstacles' that have reduced discharges to legally unacceptable levels, that is chopping down the trees in the forest, an innovative solution to enhance ecological variation and succession was actively sought by a local NGO (Stichting Ark) in cooperation with the Radboud University Nijmegen. This resulted in the initiation of a pilot project to design and implement interventions based on the concept of Cyclic Floodplain Rejuvenation (CFR) at Beuningen/Ewijk in 2004.

A project team, with representatives from Stichting Ark, the Radboud University Nijmegen, the operational arm of the ministry of Transport, Public Works and Water Management (RWS) and State Forestry was formed. The pilot project at Beuningen/Ewijk also formed a study component of the 5th framework EU Interreg IIIB research project 'Freude am Fluss' in which both the Radboud University Nijmegen and the Delft University of Technology were involved. However, in addition to the project team and the researchers, a broad range of actors have stakes in the use and management of the floodplains at Beuningen/Ewijk. These include the Beuningen Municipality, the province of Gelderland, other NGO's e.g. Geldersch Landschap, and the local landowners. Stichting Ark takes care of the daily environmental management of the area and represents more than thirty public and private landowners.

The project team held formal meetings approximately 4 times per year, but most members met more regularly through other local and regional fora. Additionally a workshop attended by a broader group of actors was held annually. Within the first year, a set of criteria to address flood defence and nature development goals and the related interests of the involved actors were agreed to by the different actors involved in the pilot project for use in the decision-making process. The first three criteria listed below reflect the mandatory requirements that the designed intervention should satisfy, while the next four criteria reflect locally and conceptually desirable elements. The last criterion was proposed by the operational river manager from the RWS and agreed to by the other actors because they wished to act expeditiously and assumed that the involvement of more actors would complicate and thus slow the process. Accordingly they chose to include only the land owners legally responsible for the decreased safety levels in the project by focusing in their design of potential interventions on the Beuningen/Ewijk floodplains alone.

- The CFR intervention should ensure that the local high water levels under the reference flood conditions (a peak discharge of $16000 \mathrm{~m}^{3} \mathrm{~s}^{-1}$ at Lobith on the Dutch-German border) decrease by at least $5.6 \mathrm{~cm}$ (Mannaerts 2004).
- Navigational conditions should not be affected adversely.

- Existing infrastructure (e.g. dikes) should not be affected by the intervention.

- The intervention should imitate natural bio-geomorphological processes.

- The intervention should increase the ecotope diversity.

- No land should become permanently inaccessible to grazers.

- Local eco-morphological features such as sand dunes should be conserved.

- The intervention should be focussed on the floodplains of Beuningen/Ewijk.

The Radboud University Nijmegen adopted a facilitatory role, designing several potential interventions in close cooperation with ecologists, river engineers and operational river managers. The designs were progressively adapted based on the interactions with experts and insights deriving from the hydrodynamic modelling. Design options included the excavation of a number of secondary channels with varying characteristics through the area of the floodplain with the highest hydraulic resistance. The secondary channels were thus designed to pass through the area with the highest elevation and densest vegetation creating (semipermanent) islands and increasing the discharge capacity of the river sufficiently to compensate for the increased hydraulic resistance provided by the forests should a flood occur. The proposed interventions met the first of the agreed criteria (Vreugdenhil 2005). In addition, bio-geomorphological processes could be imitated partially so that the ecolotope diversity could be expected to increase, satisfying the fourth and fifth criteria. The islands were not permanently cut-off from the floodplain, satisfying the sixth criteria, and local features were taken into account (e.g. reconnecting to a former side-channel) satisfying the seventh criterion. Finally, the potential interventions were all limited to the location of Beuningen/Ewijk, satisfying the eighth criterion. The intervention proposed to the project team was presented by Peters and others (2004) and is depicted in Fig. 3.

The proposed interventions were discussed at the formal project meetings and were checked for hydraulic effectiveness and feasibility by the RWS (criteria one, two and three), who functioned as quality controller. RWS raised issues such as the stability of the dike and morphological impacts on the main channel. In contrast, Stichting Ark and State Forestry focused on design characteristics such as the precise location on the floodplain and the coherence with the ecological system, as well as raising practical considerations such as costs, the impacts on grazing herbivores and the accessibility to visitors. In 2005 an intervention was designed following which a process of obtaining 
Fig. 3 A proposed CFR intervention at the sandbar of Ewijk ('De Plaat van Ewijk') (for location see Fig. 2). The CFR intervention consists of three channels ('Geul 1,2,3') connecting the river with the old disconnected channel ('Ewijkse Strang'). Additionally a crosschannel ('lateraalgeul') and a re-connection of the old channel with the main stream on the downstream side ('Verlaging uitstroom') are planned. The design aims to create a diverse landscape with semi-permanent islands incorporates ecologically important stands of vegetation such as the natural embankments colonized by pioneering plants ('Behoud beginnende oeverwal') (Source: Peters and others 2004)

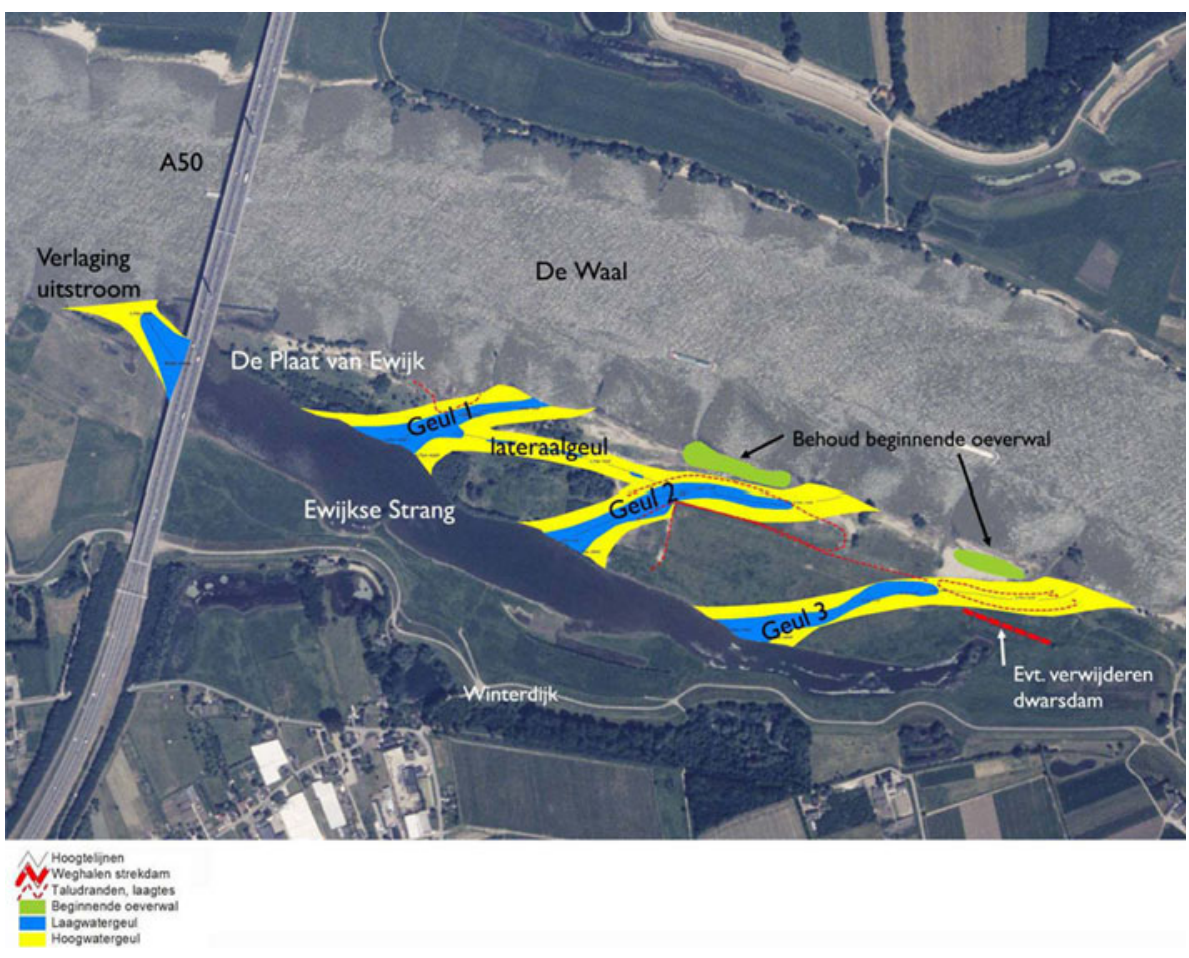

permits (e.g. for vegetation removal, soil quality, spatial plans) and further refining of the design occurred. In 2008 the implementation commenced with the removal of vegetation by a building contractor, but full implementation has still to occur. Excavation of the underlying sand is planned for 2012 when the sand can be re-used in the construction of a bridge nearby.

\section{Analysis \\ Characterizing Actors According to Their Scale Preferences}

A scale preference is the preferred focus level of an actor. It represents a complex and personal matching between the underlying disciplinary or managerial scale perspective of a particular actor and their present role and dominant tasks. The precise flavour or focus that they give to their tasks within a specific project is defined as their scale preference. This means that two individuals with the same disciplinary background, but different tasks may exhibit completely different scale preferences. For instance, an ecologist employed by State Forestry and tasked with conserving ecologically important riverine nature may exhibit a unit level scale preference (i.e. focus on conserving particular stands of alluvial forest). An ecologist employed by the regional government and tasked with overseeing nature development within the region may exhibit a river basin scale preference and focus on the degree of spatial connectedness of alluvial forests along the river continuum. Similarly, two individuals with the same tasks, but different disciplinary backgrounds may also exhibit completely different scale preferences. For example, an operational river manager with an engineering background may exhibit a floodplain level scale preference (i.e. focus on maintaining flooding safety and navigability at a local level). An operational river manager with a geomorphological disciplinary background may exhibit a meso-scale level preference and choose to focus on processes at the river reach level and how these affect the local level.

We will now group and characterise the actors participating in the Beuningen/Ewijk pilot project in terms of their scale preferences. Note that a scale preference is not a static entity. If a different problem were to be tackled in another project, the actors might change their stance and exhibit a different preference based on the different demands of their tasks within that project. Accordingly, this analyis of scale preferences applies specifically to the Beuningen/Ewijk pilot study and the demands that the innovative Cyclic Floodplain Rejuvenation concept placed on the actors involved. However, we consider the method of analysing actor-related scale preferences and mismatches to be generally applicable.

The actors actively involved in the pilot project are categorized as conservationists, operational river managers, local administrators/planners, regional administrators/ planners, river basin planners, entrepreneurs, riverine ecologists and Cyclical Floodplain Rejuvenation protagonists. By CFR protagonists we mean the group of 
Table 1 Characterization of the actors involved in the pilot project at Beuningen/Ewijk; their underlying disciplines and their current roles and dominant tasks provide an indication of the source of their scale preferences

\begin{tabular}{|c|c|c|c|}
\hline Underlying scale perspectives & Actor characterization & Roles or dominant tasks & Actors \\
\hline Ecological scale perspective & Conservationists & $\begin{array}{l}\text { Nature development-achieving desired state } \\
\text { of vegetation at local (eco-element) level } \\
\text { Recreation-sustainable use of natural } \\
\text { environment for recreation }\end{array}$ & State forestry \\
\hline $\begin{array}{l}\text { Bio-geomorphological scale } \\
\text { perspective, ecological scale } \\
\text { perspective and hydrological } \\
\text { scale perspective }\end{array}$ & CFR protagonists & $\begin{array}{l}\text { Conduct a pilot project in which cyclic } \\
\text { floodplain rejuvenation is applied } \\
\text { Research on the design of the innovation } \\
\text { Stewardship of the land } \\
\text { Nature restoration through imitation of natural } \\
\text { processes } \\
\text { Recreation-sustainable use of natural } \\
\text { environment for recreation }\end{array}$ & $\begin{array}{l}\text { Radboud University } \\
\text { Nijmegen } \\
\text { Stichting Ark }\end{array}$ \\
\hline Economic scale perspective & reneurs & $\begin{array}{l}\text { Practice agriculture, however, the majority have } \\
\text { delegated stewardship of the land to Stichting } \\
\text { Ark } \\
\text { Legally responsible for removal of obstacles to } \\
\text { flooding safety on their land } \\
\text { Legally responsible for not polluting water with } \\
\text { agricultural pollutants } \\
\text { Ensuring personal quality of life }\end{array}$ & Landowners/farmers \\
\hline Economic scale perspective & ceneurs & $\begin{array}{l}\text { Mining of sand and gravel for economic gain } \\
\text { Develop land for industrial, residential and } \\
\text { business purposes }\end{array}$ & $\begin{array}{l}\text { Mining companies } \\
\text { Industrialist/property } \\
\text { developer }\end{array}$ \\
\hline $\begin{array}{l}\text { Public administration/planning } \\
\text { scale perspective } \\
\text { Economic scale perspective }\end{array}$ & Local planner & $\begin{array}{l}\text { Compliance with spatial planning at local scale } \\
\text { Local economy } \\
\text { Recreation in Beuningen and surroundings }\end{array}$ & $\begin{array}{c}\text { Municipality of } \\
\text { Beuningen }\end{array}$ \\
\hline $\begin{array}{l}\text { Public administration/planning } \\
\text { scale perspective } \\
\text { River management scale } \\
\text { perspective } \\
\text { Economic scale perspective }\end{array}$ & Regional planner & $\begin{array}{l}\text { Compliance with regional spatial plan } \\
\text { Setting regional nature development objectives } \\
\text { in alignment with LNV and RWS (including } \\
\text { measures to expand natural areas and restore } \\
\text { the connectivity between them) } \\
\text { Economic development }\end{array}$ & $\begin{array}{l}\text { Provincial authorities } \\
\text { (Provincie } \\
\text { Gelderland) }\end{array}$ \\
\hline $\begin{array}{l}\text { River management scale } \\
\text { perspective } \\
\text { Ecological and hydrological scale } \\
\text { perspectives } \\
\text { Engineering scale perspective } \\
\text { Operational river manager }\end{array}$ & $\begin{array}{l}\text { Operational river } \\
\text { manager }\end{array}$ & $\begin{array}{l}\text { River basin planning (including setting } \\
\text { ecological objectives for water bodies) } \\
\text { Adherence to international agreements } \\
\text { Compliance with water law(ensuring safety } \\
\text { from flooding) } \\
\text { Maintaining the safety of river engineering } \\
\text { works and ensuring navigability }\end{array}$ & $\begin{array}{l}\text { Dutch Ministry of } \\
\text { Transport, Public } \\
\text { Works and Water } \\
\text { Management }\end{array}$ \\
\hline
\end{tabular}

individuals actively advocating the concept of CFR. These include the Radboud University Nijmegen and Stichting Ark. An overview of the actor characterizations based on the underlying disciplines and the roles or dominant tasks of the actors involved in the pilot project are provided in Table 1.

\section{Mismatches in Scale Preferences and Their Effects}

We visualize the mismatches in the scale preferences of the actors involved in the Beuningen/Ewijk pilot project by positioning them on the right hand side of the Integrated Scale Hierarchy (Fig. 4). We position the 
Fig. 4 The Integrated Scale Hierarchy for Rivers applied to the CFR pilot project at Beuningen/Ewijk. The scale preferences of the different actors are displayed on the right hand side. The shifts in focus required of the actors for effective CFR application are indicated by arrows

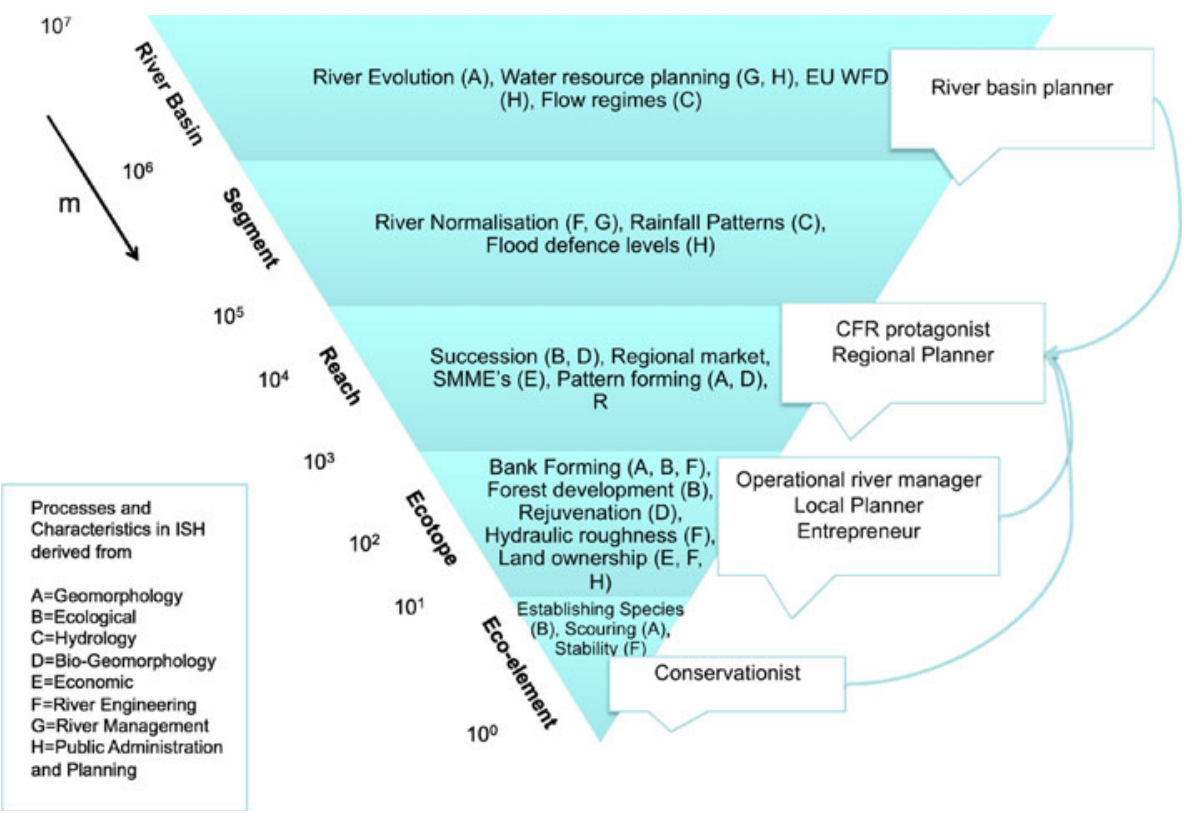

Conservationists or conservation biologists at the ecoelement level since they focus on the preservation and protection of species and species niches. The Operational river managers are placed at the floodplain/ecotope level since it is at this level that hindrances to discharge capacity are identified. The local planners also focus at this level. Similarly, the entrepreneurs are placed at the floodplain level, because the industrialists and farmers involved are local landowners. In addition, the sand and gravel mining company focus at this level in determining the economic viability of floodplain areas for mining. The CFR protagonists are positioned at the river reach level, since they focus on ecological processes such as vegetation succession and pattern development (vegetation mosaic) along the river, and on the geomorphological processes of erosion and sedimentation as well as on the hydraulic processes that influence flood defence levels. Regional planners usually focus at a similar level although their objects of interest may be very different. River basin planners focus at the catchment level for which international agreements and cooperative arrangements are relevant, while riverine ecologists have an ecological perspective on river management. They focus on adaptive water resource planning, the production, transportation and storage functions of a river and its resilience to change. These processes, concepts and their interrelations also require a highly aggregated or river basin level.

Using the Integrated Scale Hierarchy, we are able to identify similarities and differences in the foci of involved actors. For instance, the regional planners and the CFR protagonists focus at the same level, but do not necessarily share the same goal of enhancing the naturalness of rivers. Nevertheless, from an institutional perspective, regional planners fit well with CFR. In contrast, the conservationists and the CFR protagonists focus at different levels yet share the same goal. Whereas similarities and differences in goals are commonly recognized, knowing that actors have different scale preferences and visualising these can increase mutual understanding.

Additionally, the Integrated Scale Hierarchy clarifies the need for flexibility in scale use in Dutch river management if the innovative CFR concept is to be applied successfully. A major implication of CFR is the requirement it places on those involved in the design and implementation of biogeomorphological interventions to focus at the river reach level. This requires shifts in the focus levels of the characteristic actors in Dutch river management as depicted by means of arrows in Fig. 4. Operational river managers would need to zoom out from floodplain level to reach level (scale up) to use the CFR concept effectively in the operational management of floodplains. Conservationists would need to scale up and expand their focus from the ecotope level to the reach level. However, it would require increased confidence in, and knowledge of, the ability of riverine species to deal with dynamic floodplain conditions since undertaking large-scale interventions implies reduced local control and less knowledge of the precise state of species protection. In contrast, instead of focusing on enhancing ecological processes in general (at the river basin level), river planners would need to scale down and focus on enhancing ecological processes in areas where these can contribute to increasing discharge capacities locally. 
The existing mismatches in the scale preferences of the involved actors led to the strong reduction in the range of potential interventions open to investigation at the outset. Limitations were placed upon the design in a number of ways. First, the location was limited to Beuningen/Ewijk, which meant that potential interventions on nearby or downstream floodplains were not considered. The size of the intervention was limited by concerns about navigability and the required grazing access, excluding the possibility of a permanent island or a channel across the entire floodplain. Secondly, although the cyclic character of the intervention is addressed by resetting some of the stands of uniform vegetation to pioneer stages, for the intervention to become part of a cyclic strategy, similar measures would need to be designed and implemented within the same river reach in the future. At present, the design and implementation process occurs in isolation.

The first limitation set upon the CFR strategy was that floodplains further downstream and on the other side of the river were excluded at the start of the pilot project. Including these could have revealed where and how vegetation could be reset to pioneer stages and sediments reworked so that landscape mosaics typical of lowland rivers could have developed at the reach level (Peters and others 2006; Bormann and Likens 1979). However, the scale preferences of conservationists who value the presence of individual species, of land owners who are limited by the boundaries of their land and the quality of the (contaminated) soil, and particularly of river managers who can best safeguard their interests in navigation and dike stabilities at a small levels of scale, steered the focus towards a floodplain level. In contrast, using larger levels of scale than river reaches might benefit ecological purposes but no longer makes a contribution to lowering water levels at Beuningen/Ewijk. Morss and others (2005) explain that the limited willingness of practitioners to change practice as a result of change in science or technology can be understood if the multitude of constraints they work under is taken into account. These include a broad range of multi-level regulations, limited technical capacities and resources, their need to respond to multiple interests while many resources are already expended on the process (Morss and others 2005).

The floodplain of Beuningen/Ewijk does not necessarily gain most benefits from rejuvenation nor contribute most to increasing the resilience of the river system. Other potential opportunities such as lower implementation costs or coupling with existing plans (e.g. in Winssen, the floodplain directly downstream), could not be identified because these options were eliminated from consideration at an early stage.

The second limitation imposed upon the CFR strategy was that it was not considered as part of a longer term, cyclic strategy with multiple interventions, but instead as a design in isolation. At this stage, in Beuningen/Ewijk there is no future plan to follow up on the initial intervention, even though, sedimentation and vegetation development are ongoing. The period of resettlement is uncertain, however, and depends on factors such as grazing density, floods and sand supply by the river. Some actors, particularly those who have developed the concept, recognize the need for longer term perspectives, but consider this as a potential step to be taken in the future. They want the pilot at Beuningen/Ewijk to be implemented and evaluated, without 'unnecessarily' (meaning: if safety levels do not exceed the norm) spending money and/or intervening in the natural landscape.

\section{Examining the Validity of the Arguments Against} Scaling Up

In this section we explore the validity of the arguments propounded by the Dutch operational river managers and the conservationists for focusing at a floodplain rather than at a river reach level, which is a more appropriate level for designing bio-geomorphological interventions. The arguments regarding navigability, hydraulic effectiveness, managerial complexity, legislation and the presence of particular species that underlie this preference on the part of the operational river managers and conservationists can form a barrier to the implementation of the innovative Cyclic Floodplain Rejuvenation concept.

Commercial navigation is an important aspect of the Dutch economy. To safeguard the navigability of the Waal River, the morphology of the channel and flow patterns in the channel should remain stable. Since the morphological patterns in the main channel can be affected by the excavation of large volumes of sand from floodplains and knowledge of these effects is limited, smaller (local) interventions on a particular floodplain currently form standard practice in river management. The preference for small-scale measures is therefore precautionary. However, this cautious approach limits the possibility of effectively imitating natural morphodynamic processes and also the opportunity to learn about the biophysical system by trying things out.

In striving for hydraulic effectiveness, river engineers and managers tend to focus their ameliorating actions at or near the source of the increased hydraulic resistance. Their rationale for focusing at the local floodplain or even ecotope level relates primarily to an effective and efficient lowering of high water levels, since the vegetation to be removed is limited or the sand volumes to be excavated are small. However, this narrow focus precludes the exploration of potential interventions at other locations (in both the 
Fig. 5 Effects on desired water level (at $Q=16.000 \mathrm{~m}^{3} / \mathrm{s}$ ) from measures at different locations (Ewijk $=$ problem location, Loenen $=$ other side of the river, Winssen $=$ downstream). By fictitiously shifting Winssen further downstream, an indication of the longitudinal scale at which such a measure remains effective can be obtained

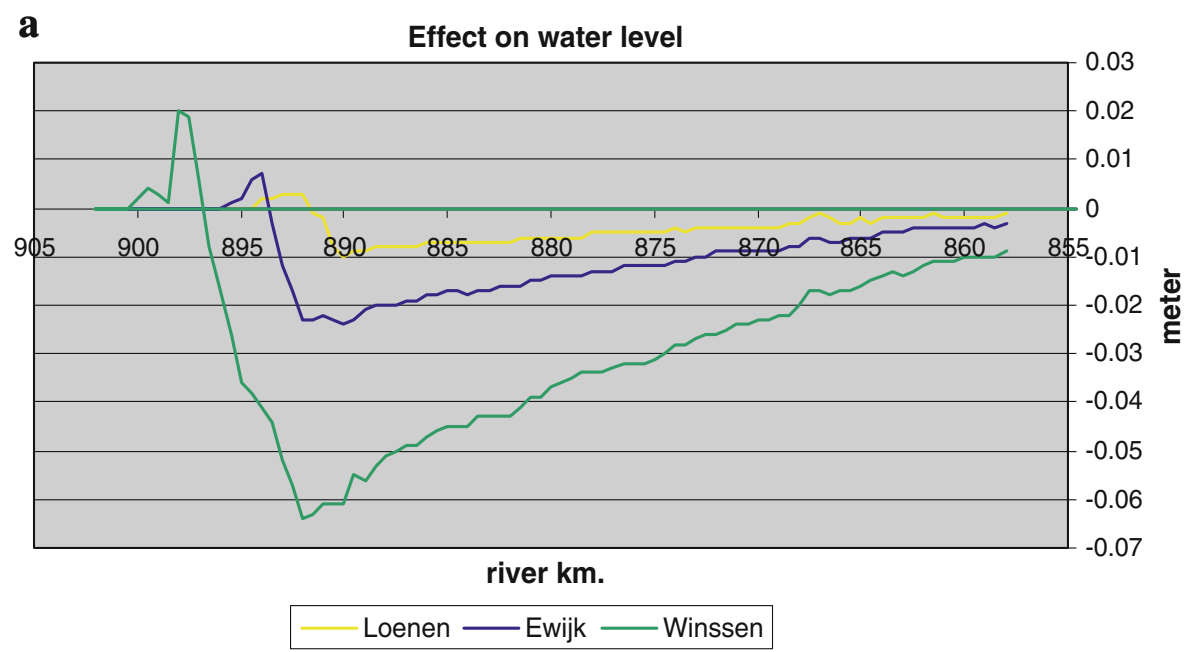

b

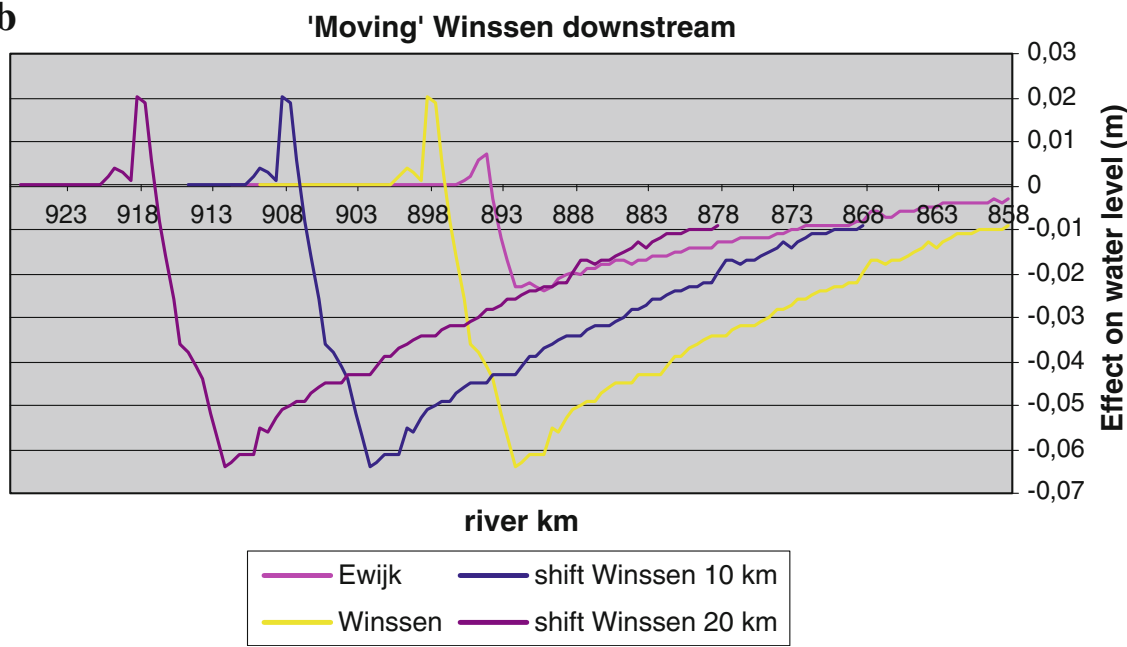

transverse and longitudinal directions) which may offer more effective means of reducing high water levels to meet the legally required flood safety standards.

Using a two-dimensional hydrodynamic model and the Blokkendoos, we illustrate the limitations of such a narrow focus by simulating the effects of potential interventions at Ewijk, Winssen, some $10 \mathrm{~km}$ downstream of Beuningen/ Ewijk and at Loenen across the river from Ewijk. The intervention proposed at Winssen is of particular interest as it reduces the local high water level at Ewijk by between 4 and $5 \mathrm{~cm}$ (Fig. 5a), meeting legal requirements. A concomitant disadvantage is that this measure causes the high water level at Winssen itself to rise by approximately $2 \mathrm{~cm}$. In addition, shifting the intervention proposed at Winssen even further downstream provides an indication of the longitudinal impact of the proposed measure (Fig. 5b). Larger interventions up to $20 \mathrm{~km}$ downstream of Beuningen/Ewijk are potentially as effective as intervening at Beuningen/Ewijk itself. The proposed interventions at Loenen, on the opposite bank of the river, are less effective. Clearly, the narrow focus on Beuningen/Ewijk precluded consideration of more effective interventions further downstream.

By considering interventions at a river reach level rather than at a local floodplain level, the managerial complexity associated with more interplay among an increased number of involved actors increases. This means that issues such as multiple objectives, the time required, the communication requirements and the financial structures would all increase in complexity (Kooiman 1993). Although an increase in the number of involved actors can delay decision-making processes, it can also succeed in increasing the resource base of the involved parties and in extending their influence in policy circles. This can, in turn, reduce resistance in later stages of the project and broaden the 'school' that is familiar with the innovation. Previously unsolved problems can become amenable to solution by linking multiple (partially shared) goals, thereby justifying the multi-faceted character of many environmental and sustainability issues, and combining resources and instruments to resolve the 
problems (Bressers and Rosenbaum 2003). In this way, single issue problems can turn into multi-issue problems with room for package deals, giving and taking, and incentives to cooperate (De Bruijn and ten Heuvelhof 2008, pp. 49-54). Clearly, the argument that scaling up would significantly increase the number of involved actors and the managerial complexity is valid, but this argument ignores the potential advantages of scaling up.

For instance, in this pilot project scaling up would require the involvement of the municipality of Winssen, which is already considering sand excavation on the floodplain. Combining such plans with a CFR intervention, could reduce costs and increase benefits. A site with available, useful and relatively clean sand is attractive for excavation by a sand mining company and the sand could be used for infrastructure projects such as bridge or road construction. A wider exploration of options (scaling up), can be of interest for financial, societal or efficient governance reasons.

Current legislation prescribing that land owners (both private and public) are responsible for maintaining the discharge capacity, provides a strong argument for river managers to focus at a local floodplain level. However, the law does not require that the 'obstacle' to flow is removed at the 'problem location'. If restoration of the river discharge capacity is undertaken on privately owned land at the problem location, there is little room to undertake innovative CFR interventions. However, governmental organisations have the obligation to 'serve societal goals' providing a contestable argument to undertake CFR measures on state land at a location other than the problem location. This argument is strengthened when the problem location is already on state land and provides a means by which river managers can ensure that they deal mainly with other public authorities. In general, the existence of state lands, i.e. public landowners, as well as foundations such as Stichting Ark which represents a group of public and private landowners, opens up the possibility of undertaking CFR interventions on the lands of actors who are not themselves legally liable. In summary, the legal argument for the strong focus on the problem location does not provide a valid basis for not scaling up to the river reach level.

Our analysis reveals that arguments related to hydraulic effectiveness, managerial complexity and legislation do not form an insurmountable barrier to scaling up from the local floodplain to the river reach level. Operational river managers can potentially enlarge their focus, but barriers still exist in the increased managerial complexity and the concerns regarding navigational safety. In the survey conducted during the CFR workshop in 2005, the majority of operational river managers agreed that the managerial complexity would increase, but expressed that they were open to exploring the opportunities and risks involved.

\section{Discussion}

River- and floodplain management in general, and the Cyclic Floodplain Rejuvenation project at Beuningen/Ewijk in particular, involve multiple actors, most of them holding different perspectives on the river system and different preferences for the scale at which their major issues can best be safeguarded. These preferences derive from their disciplinary backgrounds, their roles and dominant tasks in relation to river management and the issues and constraints they deal with. The differences between the scale preferences of the main actors and the requirements for CFR implementation provide a major reason for the sub-optimal CFR design in the case of Beuningen/Ewijk, constraining the intervention in locality and preventing effects on navigation.

By contrasting the scale preferences and foci of the actors with the scale requirements of CFR using the Integrated Scale Hierarchy, the importance of flexible scale use by the actors for the purpose of CFR application became apparent in the pilot study. This supports the widespread plea of adaptive management for more flexibility in the management of complex systems (Brunner 1994). CFR in restrained lowland rivers is based on the principles of biogeomorphological processes at the river reach level where a semi-natural floodplain landscape is created by reworking sediment patterns and resetting vegetation to pioneer stages while increasing discharge capacities. In contrast, most actors generally do not focus at this river reach level, but instead adhere to their preferred level or scale, which constrains the full application of CFR in practice. Only regional planners hold a comparable perspective and so a suggestion for future research is to focus on how this actor could play a more prominent role in floodplain management.

The operational river managers involved in the pilot project used multiple arguments to use the less appropriate floodplain level as the basis for designing the CFR measures. These included navigational stability, hydraulic effectiveness, legal responsibilities and managerial complexity. However, examining these issues from different economic, governance and hydraulic perspectives, revealed potential synergies in scaling up to the more appropriate river reach level for CFR design and implementation purposes. Opportunities that then arise include the coupling of issues (e.g. sand extraction and increasing discharge capacities), the possibility to move to areas where costs are lower (e.g. by avoidance of contaminated soil) and the inclusion of the current intervention as part of a longer term cyclic strategy instead of a design in isolation. However, the major constraining argument is the navigational stability. This issue is surrounded by uncertainties regarding morphological responses to interventions in the floodplain. 
Moreover, the importance of navigation to the Dutch justifies its being safeguarded strongly. The constraints set by navigation can only be softened if the uncertainties in morphological responses to interventions in the floodplains can be reduced.

\section{Conclusions}

Scalar problems in water governance are often ascribed to institutionalized scalar classifications and boundaries that exhibit misfits with the biophysical system (e.g., Cash and others 2006). However, we have shown that the preferred focus level or scale preference of individuals influences scale use in practice. When actors adhere to their scale preferences and these do not match well with the biogeomorphologically based concepts, this can lead to conflicts amongst actors, sub-optimal use of the concepts and sub-optimal knowledge development on the functioning of an innovative concept in interaction with its social, physical and institutional context.

The co-existence of multiple perspectives and preferences enriches the understanding of and debate about river systems and their governance. We do not argue that a specific level or scale should be preferred precisely because of the wide variety of issues and interests in river basins. This would reduce the richness of strategies to cope with these complex systems. In addition, changing institutional arrangements would simply release new issues to be dealt with. Rather, we argue for the flexible use of scales, an open attitude that 'looks outside the existing boundaries', since flexibility is generally considered a prerequisite in dealing well with environmental challenges (Meadowcroft 2002; Gunderson 1999). More specifically, flexibility in scale use could increase the robustness and resilience of the social-ecological system, since the scale use can be adapted to the needs of the moment and the biophysical processes can be used as a basis for management. However, this flexibility would not necessarily lead to more coherence in management (Benson and Jordan 2010). Such flexibility would enable practical applications of innovative concepts such as Cyclic Floodplain Rejuvenation and go some way to addressing the criticisms regarding the low level of application of adaptive and ecosystem-based management concepts (Lee 1999). In practice, flexible scale use in the design phase or early stages of management processes would enlarge the range of options considered. The difficulties anticipated in the flexible use of scale first need to be examined closely before assuming them to be insurmountable. Alternatively, if the choice is made to follow the dominant (non-fitting) scale preference, coping strategies can be developed to overcome the barriers to concept application in the future.
Acknowledgments The authors wish to acknowledge the inputs of the following people (in alphabetic order): Johan Bekhuis, Martin van Dijk, Gertjan Geerling, Mirjam de Groot, Hendrik Havinga, Wouter Helmer, Sonja Karstens, Martien Mols, Joep Mannaerts, Bart Peters, Toine Smits, Tijmen Vos, the respondents to the survey and the guest editors of the special issue, Jens Newig and Timothy Moss. The research was undertaken within the the EU-Interreg IIIB North West Europe Program 'Freude am Fluss' project and the Leven met Water Framework and partially supported by the Multi-actor Systems Research project of the Delft University of Technology and the Delft Water Research Center.

Open Access This article is distributed under the terms of the Creative Commons Attribution Noncommercial License which permits any noncommercial use, distribution, and reproduction in any medium, provided the original author(s) and source are credited.

\section{References}

Baptist MJ (2001) Review on biogeomorphology in rivers: processes and scales. Delft University of Technology, Delft

Benson D, Jordan A (2010) The scaling of water governance tasks: a comparative federal analysis of the European Union and Australia. Environmental Management. doi:10.1007/s00267009-9354-0

Bertuglia CS, Lombardo S, Nijkamp P (eds) (1998) Innovative behaviour in space and time. Springer, Berlin

Bormann FH, Likens GE (1979) Pattern and process in a forested ecosystem: disturbance, development and the steady state based on the Hubbard Brook Ecosystem Study. Springer, New York

Bressers H, Rosenbaum WA (eds) (2003) Achieving sustainable development: the challenge of governance across social scales. Praeger, Westport, London, pp 65-88. ISBN 0-275-97802-8

Brunner RD (1994) Myth and American politics. Policy Sciences 27:1-18

Cash DW, Adger WN, Berkes F, Garden P, Lebel L, Olsson P, Pritchard L, Young O (2006) Scale and cross-scale dynamics: governance and information in a multilevel world. Ecology and Society $11(2): 8$

COHS (1991) Opportunities in the hydrological sciences, National Research Council, Committee on Opportunities in the Hydrological Sciences, Water Science and Technology Board: Committee on Geosciences, Environment and Resources. National Academy Press, Washington, DC, p 348

Cooper A, Wright I, Mason T (1999) Geomorphology and sedimentology. In: Allanson B, Baird D (eds) Estuaries of South Africa. Cambridge University Press, Cambridge, pp 5-26

De Bruijn H, ten Heuvelhof E (2008) Management in networks: on multi-actor decision making. Routledge, Oxon, New York

De Bruin D, Hamhuis D, Nieuwenhuijzen L, Overmars W, Sijmons D, Vera F (1987) Plan ooievaar, de toekomst van het rivierengebied. Stichting Gelderse Milieufederatie, Rijkswaterstaat, Ministerie van LNV

De Vriend HJ, Dijkman JPM (2003) A new method of decision support to river flood management. In: Proceedings of the 1st international yellow river forum vol III, 21-24 October 2003, Zhengzhou, China

Dooge CI (1984) Waters of the earth. University College, Dublin

Duel H, Baptist MJ, Penning WE (2001) Cyclic floodplain rejuvenation: a new strategy based on floodplain measures for both flood risk management and enhancement of the biodiversity of the river Rhine. NCR publication 14-2001, Delft

Frissell CA, Liss WJ, Warren CE, Hurley MD (1986) A hierarchical framework for stream habitat classification; viewing streams in a 
watershed context. Environmental Management, 10(2): 199-214 (Springer, New York)

Geerling GJ, Ragas AMJ, Leuven RSEW, Berg JH, Breedveld M, Liefhebber D, Smits AJM (2006) Succession and rejuvenation in floodplains along the River Allier (France). Hydrobiologica 565(1):71-85

Gunderson L (1999) Resilience, flexibility and adaptive management-antidotes for spurious certitude? Conservation Ecology $3(1): 7$

Haufler JB, Wilcove D, Crowe T, Guustafson G, and Duppon D (1997) Scale phenomena, toward a scientific and social framework for ecologically basedstewardship of federal lands and waters. Draft Paper from the Ecological Stewardship Workshop, USDA Forest Service

Jewitt GPW (1998) Resolution of scale issues in an integrated catchment information sysstem for the rivers of the Kruger national park. University of Stellenbosch, Stellenbosch

Karstens S, Bots P, Thissen W (2004) Impact assessment of scale choices. In: Proceedings IAIA annual conference, Vancouver, 2004

Keeble D, Wever E (eds) (1986) New firms and regional development in Europe. Croom Helm, London

Klijn F (1997) A hierarchical approach to ecosystems and its implications for ecological land classification; with examples of ecoregions, ecodistricts and ecoseries of the Netherlands. PhD thesis. Leiden University

Kooiman J (1993) Modern governance: new government-society interactions. Sage Publications, London

Kors A (2004) The DSS 'planning kit' and its application in the Spankracht study. Lowland Technology International 6(2):67-73

Lee K (1999) Appraising adaptive management. Conservation Ecology 3(2):3

Mannaerts J (2004) Beuningse uiterwaard rivierkundige toets 2003. Rijkswaterstaat Directie Oost Nederland, Arnhem

Meadowcroft J (2002) Politics and scale: some implications for environmental governance. Landscape and Urban Planning 61:169-179

Ministry of Transport, Public Works and Water Management (2006) User's Guide WAQUA General Information version 10.43, The Hague, the Netherlands

Morss R, Wilhemi O, Downton M, Gruntfest E (2005) Flood risk, Uncertainty and Scientific Information for Decision Making. Lessons from an interdisciplinary project. Bulletin of the American Meteorological Society 86(11):1593-1601

Moss T (2007) Institutional drivers and constraints of floodplain restoration in Europe. International Journal River Basin Management 5(2):121-130

Moss T, Monstadt J (2008) Institutional dimensions of floodplain restoration in Europe: an introduction. In: Moss T, Monstadt J (eds) Restoring floodplains in europe: policy contexts and project experiences. IWA Publishing, London

Nijkamp P (2000) Entrepreneurship in a modern network economy. Research Memorandum 2000-42 Vrije Universiteit Amsterdam, Amsterdam

Peters B, Vreugdenhil HSI, Kater E, Helmer W (2004) Cyclische verjonging Ewijkse Plaat: Inrichtingsplan. Nijmegen (in Dutch)

Peters B, Geerling G, Kater E (2006) Cyclisch beheer in uiterwaarden. Natuur en veiligheid in de praktijk, Nijmegen (in Dutch)

Petts GE, Amoros C (1996) The fluvial hydrosystem. In: Petts GE, Amoros C (eds) Fluvial hydrosystem. Chapman \& Hall, London
Rijkswaterstaat R (1992) User's Guide WAQUA, Simona-report no. 92-10, Rijkswaterstaat/ICIM B.V. The Hague

Rijkswaterstaat R (2005) WAQUA berekeningen ten behoeve van afvoerstatistiek Situaties voor Rijn en Maas in 2001 en 2015. Havinga FJ (ed), Arnhem, the Netherlands

Schielen RMJ, Gijsbers PJA (2003) DSS-large rivers: developing a DSS under changing societal requirements. Physics and Chemistry of the Earth 28:635-645

Schultze RE (1995) Hydrology and Agrohydrology. A text to accompany the ACRU 3.00 Agrohydrological Modelling System. Water Research Commission Report, TT69/95. Water Research Commission, Pretria, South Africa. Pg AT1-2

Smits AJM, Havinga H, Marteijn ECL (2000) New concepts in river and water management in the Rhine river basin: how to live with the unexpected? In: Smits AJM, Nienhuis PH, Leuven RSEW (eds) New approaches to river management, Leiden

Suarez-Villa L (1996) Innovative capacity, infrastructure and regional policy. In: Batten DF, Karlsson C (eds) Infrastructure and the complexity of economic development. Springer, Berlin, pp 251270

Sutton J (1998) Market structure and innovation. MIT Press, Cambridge

Vreugdenhil HSI (2005) Cyclic floodplain rejuvenation as a river management strategy: a case study of the floodplains of Beuningen. Delft

Vreugdenhil HSI, Slinger JH, Thissen WAH, Ker Rault PA (2010) Pilot projects in water management. Ecology and Society (in press)

Vreugdenhil H, Slinger JH, Kater E (2008) Adapting scale use for successful implementation of cyclic floodplain rejuvenation in the Netherlands. In: Pahl-Wostl C, Kabat P, Moeltgen J (eds) Adaptive and integrated water management. Springer, Berlin

Young O (2002) The institutional dimensions of environmental change: fit, interplay and scale. MIT Press, Cambridge

\section{Interviewed people/ personal comments:}

J. Bekhuis, Stichting Ark

M. van Dijk, municipality Beuningen

W. Helmer, Stichting Ark

H. Havinga, Rijkswaterstaat Directorate East Netherlands/TU Delft

S. A. M. Karstens, TU Delft

J. J. H. M. Mannaerts, Rijkswaterstaat Directorate East Netherlands

M. Mols, Provincie Brabant, Nationaal park de Biesbosch

B. Peters, Radboud University Nijmegen

A. J. M. Smits, Radboud University Nijmegen, Centre for Water and Society

T. Vos, Rijkswaterstaat Directorate East Netherlands

\section{Websites}

http://www.infocentrum-binnenwateren.nl/hoogwater/ (visited 27-5-07) www.ark.eu (visited 27-5-07)

www.riza.nl (visited June-Dec 2004) 